University of Nebraska - Lincoln

DigitalCommons@University of Nebraska - Lincoln

Agronomy \& Horticulture - Faculty Publications

Agronomy and Horticulture Department

2013

\title{
Genetic Mapping and Confirmation of Quantitative Trait Loci for Seed Protein and Oil Contents and Seed Weight in Soybean
}

\author{
Safiullah M. Pathan \\ University of Missouri Delta Research Center \\ Tri Vuong \\ University of Missouri, vuongt@missouri.edu \\ Kerry Clark \\ University of Missouri, clarkk@missouri.edu \\ Jeong-Dong Lee \\ Kyungpook National University \\ J. Grover Shannon \\ Univ. of Missouri Delta Research Center, shannong@missouri.edu
}

See next page for additional authors

Follow this and additional works at: https://digitalcommons.unl.edu/agronomyfacpub

Part of the Agricultural Science Commons, Agriculture Commons, Agronomy and Crop Sciences Commons, Botany Commons, Horticulture Commons, Other Plant Sciences Commons, and the Plant Biology Commons

Pathan, Safiullah M.; Vuong, Tri; Clark, Kerry; Lee, Jeong-Dong; Shannon, J. Grover; Roberts, Craig A.; Ellersieck, Mark R.; Burton, Joseph W.; Cregan, P. B.; Hyten, David L.; Nguyen, Henry T.; and Sleper, David A., "Genetic Mapping and Confirmation of Quantitative Trait Loci for Seed Protein and Oil Contents and Seed Weight in Soybean" (2013). Agronomy \& Horticulture -- Faculty Publications. 806.

https://digitalcommons.unl.edu/agronomyfacpub/806

This Article is brought to you for free and open access by the Agronomy and Horticulture Department at DigitalCommons@University of Nebraska - Lincoln. It has been accepted for inclusion in Agronomy \& Horticulture -Faculty Publications by an authorized administrator of DigitalCommons@University of Nebraska - Lincoln. 


\section{Authors}

Safiullah M. Pathan, Tri Vuong, Kerry Clark, Jeong-Dong Lee, J. Grover Shannon, Craig A. Roberts, Mark R. Ellersieck, Joseph W. Burton, P. B. Cregan, David L. Hyten, Henry T. Nguyen, and David A. Sleper 


\section{Genetic Mapping and Confirmation of Quantitative Trait Loci for Seed Protein and Oil Contents and Seed Weight in Soybean}

Safiullah M. Pathan, Tri Vuong, Kerry Clark, Jeong-Dong Lee, J. Grover Shannon, Craig A. Roberts, Mark R. Ellersieck, Joseph W. Burton, Perry B. Cregan, David L. Hyten, Henry T. Nguyen, and David A. Sleper^

\begin{abstract}
Demand for soybean [Glycine max (L.) Merr.] meal has increased worldwide and soybean importers often offer premiums for soybean containing higher contents of protein and oil. Objectives were to detect quantitative trait loci (QTL) associated with soybean seed protein, oil, and seed weight in a soybean mapping population and confirm detected QTL across genetic backgrounds and environments. Two populations of 216 and 156 recombinant inbred lines were developed from Magellan $\times \mathrm{PI} 438489 \mathrm{~B}$ and Magellan $\times \mathrm{PI} 567516 \mathrm{C}$ crosses, respectively, and grown in two Missouri environments in 2008. More than 900 simple sequence repeat (SSR) and single nucleotide polymorphism (SNP) markers were used for mapping in each population. Across environments and genetic backgrounds, we have identified seven QTL for protein, six for oil, and four for seed weight. Two QTL were detected in common for protein and oil, one on chromosome (Chr.) 5 and another on Chr. 6. Additionally, we have detected one new seed weight QTL on Chr. 6, in the same region of protein and oil QTL. Confirmed protein and oil QTL on Chrs. 5 and 6 may be important targets to find candidate genes involved in modification of protein and oil contents and seed weight using genetic and genomic approaches. Also, SSR and SNP markers closely associated with these QTL can be useful for marker-assisted selection.
\end{abstract}

S.M. Pathan and J.G. Shannon, National Center for Soybean Biotechnology (NCSB) and Division of Plant Sciences, Univ. of Missouri Delta Research Center, Portageville, MO 63873; T. Vuong, K. Clark, H.T. Nguyen, and D.A. Sleper, NCSB and Division of Plant Sciences, Univ. of Missouri, Columbia, MO 65211; C.A. Roberts, Division of Plant Sciences, Univ. of Missouri, Columbia, MO 65211; M.R. Ellersieck, Division of Statistics, Univ. of Missouri, Columbia, MO 65211; J.W. Burton, Soybean and Nitrogen Fixation Research Unit, USDA-ARS, Raleigh, NC 27607; D.L. Hyten, Pioneer Hi-Bred International Inc., Johnston, IA 50131; P.B. Cregan, Soybean Genomics and Improvement Laboratory, USDA-ARS, Beltsville, MD 20705; J.-D. Lee, School of Applied Biosciences, Kyungpook National Univ., Daegu 702-701, Republic of Korea. S.M. Pathan and T. Vuong contributed equally to the article. Received 5 Mar. 2012. *Corresponding author (sleperd@missouri.edu).

Abbreviations: BREC, Bradford Research and Extension Center; Chr., chromosome; DRC, Delta Research Center; $H^{2}$, broad-sense heritability; LOD, logarithm of the odds; MPB, Magellan $\times$ PI 438489B; MPC, Magellan $\times$ PI 567516C; MQM, multiple-QTL method; MU, University of Missouri-Columbia; NIR, near-infrared reflectance; QTL, quantitative trait loci; RIL, recombinant inbred line; SBM, soybean meal; SCN, soybean cyst nematode; SNP, single nucleotide polymorphism; SSR, simple sequence repeat.

$\mathrm{T}$ He United States is the leading world soybean producer and exporter of soybean as whole bean, oil, and soybean meal (SBM). Important uses of soybean are protein rich SBM for livestock feed and oil for human consumption. Recently, demand for SBM has increased worldwide and the current standard for high-protein SBM is $480 \mathrm{~g} \mathrm{~kg}^{-1}$ crude protein. Soybean prices are determined primarily by protein and oil contents (Brumm and Hurburgh, 1990; Hurburgh,

Published in Crop Sci. 53:765-774 (2013).

doi: 10.2135/cropsci2012.03.0153

(C) Crop Science Society of America | 5585 Guilford Rd., Madison, WI 53711 USA

All rights reserved. No part of this periodical may be reproduced or transmitted in any form or by any means, electronic or mechanical, including photocopying, recording, or any information storage and retrieval system, without permission in writing from the publisher. Permission for printing and for reprinting the material contained herein has been obtained by the publisher. 
1994; Orf and Helms, 1994) and soybean importers often offer premiums for soybean containing higher amounts of protein and oil. Soybean provides $68 \%$ of the edible consumption of fats and oils in the United States (SOYSTATS, 2011). Also, soybean is used as an industrial and pharmaceutical raw material for production of biodiesel and soy foods. Seed protein and seed size play significant roles in determining quality of soy food products (Clarke and Wiseman, 2000; Friedman and Brandon, 2001). Small seeded soybean is generally used for soy sprouts, miso, and natto while large seeded soybean with higher protein content is desirable for tofu and edamame. Other than economic and nutritional importance, different clinical studies also suggested that soybean has numerous human health benefits such as a reduction in cancer, a decrease in blood cholesterol, and reduction of osteoporosis and heart disease. It also serves as a good source of minerals, vitamin B, folic acid, and isoflavones (Birt et al., 2004; Wilson, 2004).

There exist a wide range of genetic variation in protein and oil contents among accessions of the USDA Soybean Germplasm Collection but it is extremely rare to find an accession with higher contents of both protein and oil (Wilson, 2004). Protein and oil are genetically negatively correlated (Burton, 1987; Wilcox, 1998), which makes it difficult to improve both traits simultaneously. Yield is genetically negatively correlated with protein content but positively correlated with oil (Burton, 1987; Wilcox and Goudong, 1997). Heritability of soybean seed protein and oil contents are moderately high to high (Brim, 1973; Burton, 1987) and primarily governed by additive genetic effects (Thorne and Fehr, 1970). In the last 20 yr (1986 to 2004), soybean yield has increased significantly at a rate of $10.9 \mathrm{~kg} \mathrm{ha}^{-1} \mathrm{yr}^{-1}$ (USDA, 2005). Brumm and Hurburgh (2006) on their survey (1994 to 2004) reported that U.S. average oil content did not change, but average protein content dropped by $0.1 \%$ relative to the previous survey because soybean breeders have maintained protein levels while increasing yield. Mahmoud et al. (2006) also reported a decline in protein content after six decades of selection and breeding. It is difficult to simultaneously improve protein and oil content; however, it is possible to improve either seed trait consecutively (Burton, 1987; Thorne and Fehr, 1970). Current seed protein content generally meets industrial standards (Brumm and Hurburgh, 2006), but fluctuations in environmental conditions may lower protein content below the standard (Rotundo et al., 2009). Under water stress, seed protein tends to decrease and oil tends to increase (Specht et al., 2001) and seed oil also increases at high temperatures during seed development (Brumm and Hurburgh, 2006). Significant variations in seed composition at different regions within the United States have been reported (Brumm and Hurburgh, 2006).

Protein, oil, and seed size are quantitative traits controlled by multiple genes having small or large effects
(Hyten et al., 2004). Therefore, molecular markers may be helpful to identify quantitative trait loci (QTL) controlling these traits. Ultimately, these markers when confirmed may be used in marker-assisted breeding. For last two decades, several studies have identified QTL for soybean seed protein and oil contents and seed weight (Diers et al., 1992; Hyten et al., 2004; Mansur et al., 1996; Orf et al., 1999; Panthee et al., 2005; Specht et al., 2001). To discover new QTL, scientists have developed and used mapping populations from an interspecific cross between Glycine max (cultivated soybean) and Glycine soja Siebold \& Zucc. (wild soybean) (Diers et al., 1992; Sebolt et al., 2000). They also used soybean Plant Introductions as both parents for the mapping populations (Mansur et al., 1996; Specht et al., 2001), Plant Introductions as one of the parents (Orf et al., 1999; Fasoula et al., 2004), and soybean cultivars and/or advanced breeding lines as both parents (Hyten et al., 2004; Panthee et al., 2005; Reinprecht et al., 2006). Researchers also used a single large mapping population to detect QTL with minor effects (Mansur et al., 1996; Orf et al., 1999; Specht et al., 2001) or used numerous small populations with different parental combinations to detect major QTL and to validate identified QTL across different genetic backgrounds (Brummer et al., 1997). Hyten et al. (2004) summarized reported QTL for protein and oil contents and seed weight with their genetic locations, effects, significance, and mapping parents. Currently, SoyBase (http://soybase.org, accessed 12 Feb. 2012) reported a large number of QTL for different seed traits, including 115 for protein, 113 for oil, five for protein and oil, and 120 for seed weight. Genetic positions of some of these reported QTL are very close $(<10 \mathrm{cM})$ so they may not be truly different QTL. Among these, only a few have been confirmed so far (Fasoula et al., 2004). To verify stable QTL, it is important to identify QTL from many populations developed from diverse parents and to evaluate in multiple locations. For example, one of the most consistent protein and oil QTL on chromosome (Chr.) 20 was identified in different environments and genetic backgrounds and mapped between map positions of 32.4 to 39.4 cM (Brummer et al., 1997; Chung et al., 2003; Diers et al., 1992; Nichols et al., 2006; Sebolt et al., 2000; Specht et al., 2001). Some of this high protein QTL have pleiotrophic effects or are associated with reduced oil (Diers et al., 1992; Chung et al., 2003; Sebolt et al., 2000). A protein and oil QTL was mapped on Chr. 5 between map positions 93.6 to 94.9 cM in three independent studies (Mansur et al., 1996; Orf et al., 1999; Specht et al., 2001). Also on Chr. 7, a protein QTL was mapped between map position 33.5 and $41.9 \mathrm{cM}$ in four studies (Csanadi et al., 2001; Hyten et al., 2004; Orf et al., 1999; Specht et al., 2001). Some of these QTL were detected in a single population, for example seed weight QTL on Chr. 10 (Csanadi et al., 2001).

Although a large number of QTL have been identified for protein and oil contents and seed weight, only a few QTL have been confirmed across genetic backgrounds and/or 
environments. Population size (small to moderate mapping population sizes), genetic background of parental lines, environments, phenotyping methods, and use of different molecular markers (variation in polymorphisms level) are possible reasons for inconsistency with previously detected QTL. The objectives of the current study were (i) to detect QTL associated with soybean seed protein and oil contents and seed weight in a recombinant inbred line (RIL) population derived from a Magellan $\times$ PI 438489B cross, (ii) to confirm detected QTL in a different RIL population derived from a Magellan $\times$ PI 567516C cross, and (iii) to identify possible genotype $\times$ environment interactions in seed traits.

\section{MATERIALS AND METHODS}

\section{Plant Materials}

Two mapping populations were developed from a cross of Magellan $\times$ PI 438489B (henceforth designated as MPB) and Magellan $\times$ PI 567516C (henceforth designated as MPC). Magellan (PI 595362) (Schapaugh et al., 1998) is a high-yielding cultivar with lower seed protein and higher oil contents than standard cultivars. Plant Introduction 438489B and PI 567516C are soybean cyst nematode $(\mathrm{SCN})$ resistant germplasm with black and greenish-brown seed coat colors, respectively, and higher seed protein and lower oil content than standard cultivars. Both PI 438489B and PI 567516C originated from China (Yue et al., 2000; USDA-ARS-GRIN, 2012). Crosses were made at the Bradford Research and Extension Center (BREC) of the University of Missouri-Columbia (MU) in the summer of 2005. The $\mathrm{F}_{1}$ 's were harvested in October and then sent to Costa Rica for generation advancement. Generations were advanced until the $F_{5}$ stage via single-seed descent method (Brim, 1966). The $\mathrm{F}_{5}$ single plants were harvested and threshed separately and were grown in rows, harvested row in bulk, and then advanced to the next generation. Initially, these two populations were developed and used for mapping of SCN (Vuong et al., 2010, 2011). The $\mathrm{F}_{5: 7}$ seeds of 216 RILs of the MPB and 156 RILs of the MPC populations and parents were planted in $2.7 \mathrm{~m}$ long plots with $0.75 \mathrm{~m}$ spacing between rows. Three replications in a randomized complete block design were grown at BREC, Columbia, $\mathrm{MO}$, and the MU Delta Research Center (DRC) in Portageville, MO, in the summer of 2008. All three parents (Magellan, PI 438489B, and PI 567516C) are classified as maturity group IV.

\section{Phenotypic Analysis}

Approximately 5 to $6 \mathrm{~g}$ of whole soybean seed was used to quantify seed protein and oil contents using near-infrared reflectance (NIR) spectroscopy according to procedures of Duckworth (1998) and Shenk and Westerhaus (1991). Lines with cracked seed coat of both populations were excluded from analysis and all other seeds (black, brown, green, and yellow) were included for analysis. The spectrophotometer was a FOSS NIRSystems 6500; the software used to store spectra and develop calibrations was WinISI version 1.02 (InfraSoft, 1999). Two individual samples from each replication of each location were analyzed at regular intervals to confirm repeatability of measurements. Samples were double scanned and the
Table 1. Calibration statistics for near-infrared spectroscopic determination of soybean seed protein and oil contents.

\begin{tabular}{ccccccc}
\hline Trait & No. of RILs & Mean & SEC $^{\ddagger}$ & SECV & $R^{2}$ & $1-$ VR $^{\text {q }}$ \\
\cline { 3 - 7 } Protein & 63 & 394.4 & 5.8 & 8.9 & 0.93 & 0.84 \\
Oil & 63 & 170.8 & 2.2 & 4.7 & 0.97 & 0.85 \\
\hline
\end{tabular}

${ }^{\dagger} \mathrm{RIL}$, recombinant inbred line.

łStandard error of calibration (SEC) calculated in modified partial least squares regression.

§Standard error of cross validation (SECV) calculated in modified partial least squares regression.

"One minus the variance ratio (VR) calculated in cross validation in modified partial least squares regression.

\#DM, dry matter.

spectra averaged. Chemical analysis of 63 RILs of different seed colors were also performed for cross-validation. Protein was determined by combustion (Eurofins test ID QD052 [AOAC Int., 2005]), and oil was determined by ethyl ether extraction (Eurofins test ID QD061 [AOAC Int., 2005]). A calibration was developed by regressing chemical data against spectral data using partial least squares regression over the entire spectra (400 to $2500 \mathrm{~nm}$ ) with six validation groups. Math treatment used the second derivative of $\log 1$ - reflectance $(\mathrm{R})$ with a standard normal variance pretreatment (Barnes et al., 1989). The optimum calibrations were selected on the basis of low standard errors and high squared correlation coefficients (Table 1).

Seed weight was determined by weighing 100 random seeds per plot. Genomic DNA extraction and molecular marker analysis (simple sequence repeat [SSR] and single nucleotide polymorphism [SNP]) were performed as previously described (Vuong et al., 2010).

\section{Data Analysis}

Phenotypic data for seed protein and oil contents and seed weight were subjected to an ANOVA using the PROC GLM (general linear model) mixed model of SAS version 9.2 (SAS Institute, 2002). The linear statistical model contains the effects of environment, replication within environment, genotype, and environment $\times$ genotype interaction. Environment, genotype, and environment $\times$ genotype interaction were considered as fixed effects. Replication within environment was used as the denominator of the $F$-value of environment. The residual mean square was used to test genotype and genotype $\times$ environment interaction. Broad-sense heritability $\left(H^{2}\right)$ of each trait was estimated on an entry mean basis following Nyquist (1991):

$$
H^{2}=\left(\sigma_{\mathrm{g}}^{2}\right) /\left[\sigma_{\mathrm{g}}^{2}+\left(\sigma_{\mathrm{ge}}^{2} / e\right)+\left(\sigma^{2} / r e\right)\right]
$$

in which $\sigma_{\mathrm{g}}^{2}$ is genetic variance, $\sigma_{\mathrm{ge}}^{2}$ is genotype $\times$ environment variance, $\sigma^{2}$ is error variance, $r$ is number of replications, and $e$ is the number of environments. Phenotypic correlations were determined using the PROC CORR procedure of SAS. Genetic correlations were calculated using the following formula (Falconer and Mackay, 1996):

$$
r_{\mathrm{G}}=\operatorname{Cov}_{x y} /\left(\sigma^{2}{ }_{x} \sigma^{2}{ }^{2}\right)^{1 / 2} \text {, }
$$

in which $r_{\mathrm{G}}$ represents genetic correlation, Cov represents genetic covariance, $x$ represents the first trait, $y$ represents the second trait, and $\sigma^{2}$ is genetic variance. Cross-products between traits were generated using PROC GLM procedure of SAS with MANOVA (multivariate analysis of variance) option. 
Table 2. Mean, range, standard deviation, and heritability for seed protein and oil contents and seed weight in $F_{5: 7}$ derived two soybean populations, Magellan $\times$ PI 438489B (216 recombinant inbred lines [RILs]) and Magellan $\times$ PI 567516C (156 RILs) averaged over two environments in Missouri in summer 2008.

\begin{tabular}{|c|c|c|c|c|c|c|c|c|c|c|c|c|c|}
\hline \multirow[b]{2}{*}{ Traits } & \multicolumn{5}{|c|}{ Magellan $\times$ PI 438489B } & \multicolumn{5}{|c|}{ Magellan $\times$ PI 567516C } & \multicolumn{3}{|c|}{ Parents } \\
\hline & Mean & Range & SD & $P$-value & $H^{2 \dagger}$ & Mean & Range & SD & $P$-value & $H^{2 \dagger}$ & $\mathrm{P}^{\ddagger} \neq$ & $\mathrm{P} 2^{\S}$ & P3? \\
\hline Protein, $\mathrm{g} \mathrm{kg}^{-1}$ & 413 & $371-452$ & 21 & $<0.0001$ & 0.63 & 412 & $347-466$ & 26 & $<0.0001$ & 0.76 & 380 & 412 & 405 \\
\hline Oil, $\mathrm{g} \mathrm{kg}^{-1}$ & 180 & 163-203 & 11 & $<0.0001$ & 0.62 & 181 & 156-206 & 13 & $<0.0001$ & 0.66 & 202 & 160 & 170 \\
\hline Seed weight, g per 100 seed & 13 & $9-18$ & 1.6 & $<0.0001$ & 0.75 & 10 & $6-16$ & 1.5 & $<0.0001$ & 0.86 & 15 & 11 & 5 \\
\hline
\end{tabular}

${ }^{+} H^{2}$, broad-sense heritability, calculated on an entry mean basis.

扯, Magellan.

§P2, PI 438489B.

१P3, PI 567516C.

\section{Linkage Mapping and Quantitative Trait Loci Analysis}

Two genetic linkage maps constructed earlier for the MPB and MPC populations (Vuong et al., 2010, 2011) were used in this study. Phenotypic data for seed protein and oil contents obtained through NIR and seed weight of each location were used for QTL analysis. The QTL for protein and oil contents and seed weight were initially predicted using the interval mapping method. Subsequently, the multiple-QTL method (MQM) with the program MapQTL 5.0 (van Ooijen, 2004) was used to declare a significant QTL based on appropriate cofactors (van Ooijen and Voorrips, 2001) and a logarithm of the odds (LOD) score generated by the genomewide permutation tests (Churchill and Doerge, 1994). The confidence interval for QTL location was estimated using 1 - LOD support interval value as described by van Ooijen (1992). The proportion of the phenotypic variance explained by the QTL effects was estimated by MQM at QTL peaks. The molecular genetic maps with QTL intervals and LOD plots were subsequently created using the MapChart 2.2 program (Voorrips, 2002).

\section{RESULTS}

Two genetic linkage maps were constructed using RILs of the MPB and MPC populations with more than 900 polymorphic SSR and SNP markers (Vuong et al., 2010, 2011). Overall, marker order between loci of our newly constructed genetic maps was in good agreement with the soybean consensus genetic map (Hyten et al., 2010). Approximately 95\% of the soybean genome was covered by both of the new MPB and MPC genetic maps. More than 700 polymorphic SNP markers of the USLP 1.0 array (Hyten et al., 2010) and 200 SSR markers were used to detect QTL for soybean seed protein and oil contents and seed weight.

\section{Analyses of Seed Protein and Oil Contents and Seed Weight}

There were significant differences $(P<0.0001)$ among RILs for seed protein content in both MPB and MPC populations (Table 2). Seed protein content in MPB ranged from 371 to $452 \mathrm{~g} \mathrm{~kg}^{-1}$ with a mean of $413 \mathrm{~g} \mathrm{~kg}^{-1}$ and in MPC ranged from 347 to $466 \mathrm{~g} \mathrm{~kg}^{-1}$ with a mean of $412 \mathrm{~g} \mathrm{~kg}^{-1}$ on dry weight basis. The RILs were normally distributed for seed protein in both mapping populations and there was no transgressive segregation for protein in
MPB population (Fig. 1a; Table 2). There was significant transgressive segregation for protein in MPC. There were significant differences $(P<0.0001)$ among RILs for seed oil content in both the MPB and MPC populations (Table 2). Seed oil content in MPB ranged from 163 to $203 \mathrm{~g} \mathrm{~kg}^{-1}$ with a mean of $180 \mathrm{~g} \mathrm{~kg}^{-1}$ and in MPC ranged from 156 to $206 \mathrm{~g} \mathrm{~kg}^{-1}$ with a mean of $181 \mathrm{~g} \mathrm{~kg}^{-1}$ on dry weight basis. The RILs were normally distributed for seed oil in both populations and transgressive segregation was not observed for oil (Fig. 1b; Table 2). Seed weight in MPB ranged from 8.7 to $17.5 \mathrm{~g}$ with a mean of $12.7 \mathrm{~g}$ per 100 seed and in MPC ranged from 6.2 to $16.4 \mathrm{~g}$ with mean a of $9.5 \mathrm{~g}$ per 100 seed. The parent PI 567516C had lower seed weight of $4.7 \mathrm{~g}$ per 100 seed. The RILs were normally distributed for seed weight in both the populations and transgressive segregation was not observed (Fig. 1c; Table 2).

In MPB, entry mean basis heritabilities for protein, oil, and seed weight were $0.63,0.62$, and 0.75 , respectively. In MPC, heritabilities for protein, oil, and seed weight were $0.76,0.66$, and 0.86 , respectively, indicating much of the variation observed among RIL was genetic (Table 2). In both populations, significant negative phenotypic $(r=-0.64, P<0.0001)$ and genotypic (in MPB, $r=-0.58$, $P<0.0001$, and in MPC, $r=-0.75, P<0.0001)$ correlation between protein and oil was observed. Phenotypic and genotypic correlations for seed weight with protein and oil contents were nonsignificant and inconsistent (Table 3).

\section{Quantitative Trait Loci Analyses for Seed Protein and Oil Contents and Seed Weight}

Based on a genomewide permutation test, LOD threshold of $3.0(P=0.05), 3.1(P=0.05)$, and $3.1(P=0.05)$ were used to declare significant QTL for seed protein and oil contents and seed weight, respectively, in both MPB and MPC populations. A total of seven QTL for seed protein were mapped on Chrs. $3,5,6,7,8$, and 15 with LOD scores ranging from 2.7 to 6.7 and total phenotypic variation explained by individual QTL ranged from 4.8 to $14.2 \%$ (Table 4). Among them, one significant protein QTL mapped on Chr. 6 (between markers BARC-059985-16274 and BARC-044639-08743) was consistent across environments and genetic backgrounds. The three other protein QTL mapped on Chrs. 5 (between 


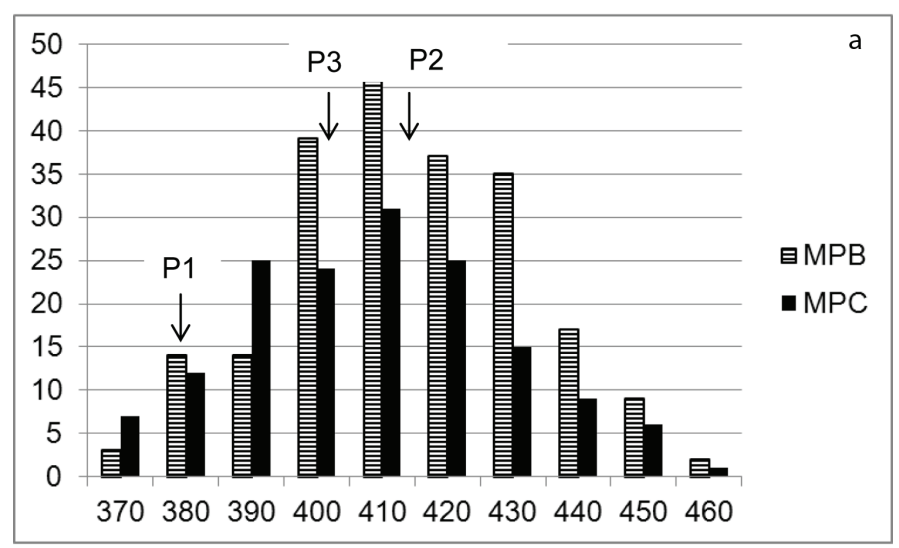

Protein $\mathrm{g} \mathrm{Kg}^{-1}$

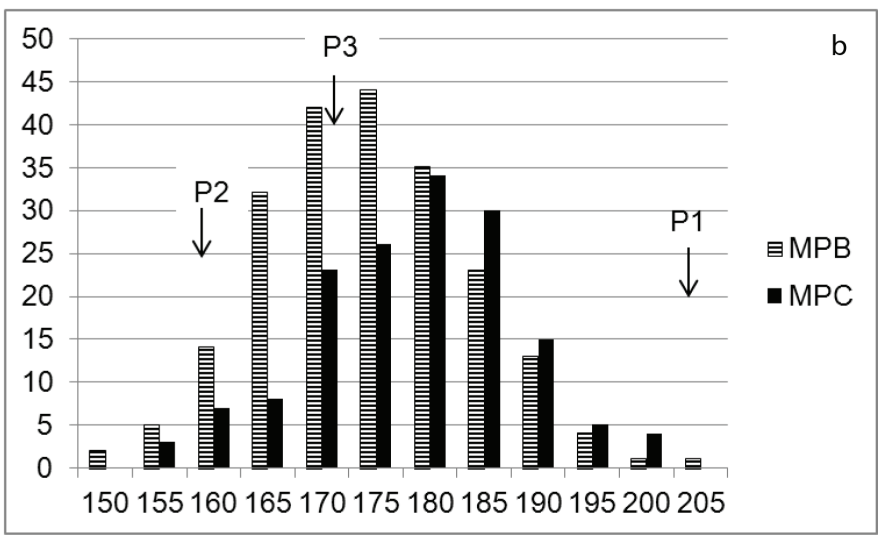

Oil $\mathrm{g} \mathrm{Kg}^{-1}$

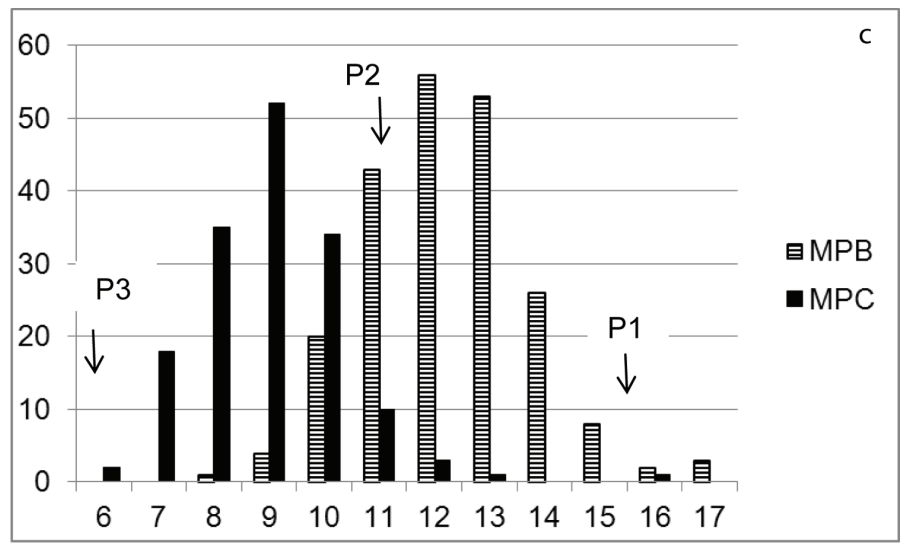

Seed weight g per 100 seed

Figure 1. Frequency distribution of (a) seed protein $\left(\mathrm{g} \mathrm{kg}^{-1}\right)$, (b) oil content $\left(\mathrm{g} \mathrm{kg}^{-1}\right)$, and (c) seed weight (g per $100 \mathrm{seed}$ ) of $216 \mathrm{~F}_{5: 7}$ recombinant inbred lines (RILs) of Magellan (Parent 1 [P1]) $\times$ PI 438489B (Parent 2 [P2]) (MPB) (striped bar) and 156 $\mathrm{F}_{5: 7}$ RILs of Magellan (P1) $\times$ PI 567516C (Parent 3 [P3]) (MPC) (solid bar) averaged over two environments in Missouri (Bradford Research and Extension Center and Delta Research Center) in summer 2008.
Table 3. Genetic (lower left diagonal) and phenotypic correlations (upper right diagonal) among protein, oil, and seed weight in $\mathrm{F}_{5}$-derived 216 recombinant inbred lines (RILs) of Magellan $\times$ PI 438489B (MPB) and $F_{5}$-derived 156 RILs of Magellan $\times$ PI 567516C (MPC) averaged over two environments (Columbia, MO, and Portageville, MO) in 2008. The first number represents MPB (open) and the second number (in parenthesis) represents MPC populations.

\begin{tabular}{lccc}
\hline & Protein & Oil & Seed weight \\
\hline Protein & & $-0.64^{\star \star \star}\left(-0.64^{\star \star \star}\right)$ & $-0.02 \mathrm{~ns}^{\dagger}\left(0.2^{\star \star \star}\right)$ \\
Oil & $-0.58^{\star \star \star}\left(-0.75^{\star \star \star}\right)$ & & $-0.006 \mathrm{~ns}(0.04 \mathrm{~ns})$ \\
Seed & $-0.16^{\star}\left(0.38^{\star \star *}\right)$ & $0.07 \mathrm{~ns}\left(-0.27^{\star \star}\right)$ & \\
weight & & & \\
\hline
\end{tabular}

*Significant at the 0.05 probability level.

**Significant at the 0.01 probability level.

${ }^{* \star *}$ Significant at the 0.001 probability level.

${ }^{\dagger}$ ns, not significant $(P>0.05)$.

BARC-041257-07953 and BARC-060051-16321), 7 (between BARC-014705-01623 and BARC-02982506442), and 8 (between Satt632 and BARC-040339-07715) were detected in both environments and in one of the populations. One protein QTL mapped on Chr. 3 (between BARC-028645-05979 and BARC-055149-13089) was identified in both populations and in one of the environments. Two other QTL mapped on Chrs. 6 (between Satt433 and BARC-049601-09082) and 15 (between BARC-01892303037 and BARC-025493-06513) were detected in only one population and one environment. In most of the cases, both PI 438489B and PI 567516C contributed positive alleles and in two cases Magellan contributed positive alleles (Chr. 3 and 6) that increase protein content.

A total of six QTL for seed oil content were identified and mapped on Chrs. 2, 3, 5, 6, and 15 (Table 4). Among them, one QTL on Chr. 5 (between markers BARC-041257-07953 and BARC-060051-16321) and another on Chr. 6 (between BARC-059985-16274 and Sat_336) were detected in both environments and genetic backgrounds. The oil QTL on Chr. 6 was consistent with the protein QTL identified in the same genomic region in both populations and environments. The oil QTL on Chr. 5 was consistent with the protein QTL identified in the same genomic region in one population and both environments. Two other QTL, one on Chr. 2 (between BARC-028373-05856 and Sat_198) and another on 15 (between markers BARC-039687-07541 and BARC042349-08247), were detected in both environments and one of the populations. Two more QTL on Chrs. 3 and 15 were detected in one of the populations and environments. Cultivar Magellan contributed favorable alleles that increase oil content in all QTL except one on Chr. 3.

Four QTL associated with seed weight were mapped on Chrs. 1, 6, and 19 across environments and genetic backgrounds (Table 4). Among them, QTL on Chrs. 6 (between markers BARC-059997-16280 and Sat_336) and 19 (between BARC-014885-01914 and Satt527) were detected across environments and genetic backgrounds. In addition, 
Table 4. Quantitative trait loci (QTL) for soybean seed protein and oil contents and seed weight were detected with multiple-QTL method in two recombinant inbred line mapping populations, Magellan $\times$ PI 438489B and Magellan $\times$ PI 567516C, evaluated in replicated trials in two environments, Bradford Research and Extension Center (BREC), Columbia, MO, and Delta Research Center (DRC), Portageville, MO, in summer 2008.

\begin{tabular}{|c|c|c|c|c|c|c|c|c|c|}
\hline Population $^{\dagger}$ & Environment & $\begin{array}{c}\text { Chr. } \\
\text { no. }\end{array}$ & Marker interval of QTL position & $\begin{array}{l}\text { Map position§ } \\
\text { (cM) }\end{array}$ & $\begin{array}{c}\text { Confidence } \\
\text { interval"1 (cM) }\end{array}$ & LOD\# & $\begin{array}{l}R^{2} \\
\quad(\%) \\
\end{array}$ & $\begin{array}{l}\text { Additive } \\
\text { effect }^{\dagger \dagger}\end{array}$ & $\begin{array}{c}\text { Total } \\
\text { PVE } \neq \ddagger(\%)\end{array}$ \\
\hline \multicolumn{10}{|c|}{ Protein content } \\
\hline \multirow[t]{6}{*}{ MPB } & BREC & 3 & BARC-016199-02307_BARC-053313-11792 & 22.3 & 21.0-23.6 & 3.3 & 5.6 & 0.47 & 21.5 \\
\hline & & 6 & BARC-059985-16274_BARC-044639-08743 & 34.4 & $33.3-35.5$ & 3.1 & 5.3 & -0.46 & \\
\hline & & 7 & BARC-014705-01623_BARC-029825-06442 & 44.3 & $42.6-46.0$ & 3.7 & 6.8 & -0.54 & \\
\hline & $\mathrm{DRC}$ & 6 & Satt281_BARC-059997-16280 & 38.9 & $38.2-39.6$ & 2.7 & 4.8 & -0.35 & 15.1 \\
\hline & & 15 & BARC-018923-03037_BARC-025493-06513 & 11.9 & $9.9-13.9$ & 4.0 & 7.5 & -0.44 & \\
\hline & & 7 & BARC-014705-01623_BARC-029825-06442 & 44.3 & $43.3-45.3$ & 3.0 & 7.0 & -0.45 & \\
\hline \multirow[t]{8}{*}{ MPC } & BREC & 3 & BARC-028645-05979_BARC-055149-13089 & 21.1 & $19.7-22.5$ & 3.4 & 6.7 & 0.70 & 34.4 \\
\hline & & 5 & Satt236_BARC-041257-07953 & 80.8 & $79.6-82.0$ & 3.2 & 6.4 & -0.70 & \\
\hline & & 6 & Satt433_BARC-049601-09082 & 114.9 & $113.6-116.2$ & 3.3 & 7.6 & 0.85 & \\
\hline & & 8 & Satt632_BARC-040339-07715 & 46.3 & $41.6-51.0$ & 6.7 & 14.2 & -1.04 & \\
\hline & $\mathrm{DRC}$ & 5 & BARC-041257-07953_BARC-060051-16321 & 78.8 & $76.8-80.8$ & 4.0 & 7.7 & -0.63 & 35.0 \\
\hline & & 6 & BARC-059985-16274_Satt291 & 34.4 & $31.7-37.1$ & 4.7 & 9.0 & -0.63 & \\
\hline & & 8 & Satt632_BARC-010097-00518 & 46.3 & $44.7-47.9$ & 3.6 & 6.8 & -0.55 & \\
\hline & & & Oil content & & & & & & \\
\hline \multirow[t]{6}{*}{ MPB } & BREC & 3 & BARC-055637-13558_BARC-057823-14942 & 27.6 & $26.5-28.7$ & 3.1 & 5.6 & -0.24 & 20.1 \\
\hline & & 6 & BARC-059985-16274_BARC-044639-08743 & 34.4 & $32.2-36.6$ & 4.2 & 7.4 & 0.27 & \\
\hline & & 15 & BARC-039687-07541_BARC-042349-08247 & 18.7 & $17.7-19.7$ & 3.0 & 5.3 & 0.23 & \\
\hline & $\mathrm{DRC}$ & 5 & BARC-041257-07953_BARC-060051-16321 & 78.8 & $76.6-81.0$ & 4.2 & 7.1 & 0.25 & 24.5 \\
\hline & & 6 & BARC-059985-16274_BARC-044639-08743 & 34.4 & $30.8-38.0$ & 5.6 & 9.3 & 0.27 & \\
\hline & & 15 & BARC-039687-07541_BARC-042349-08247 & 18.7 & $15.1-22.3$ & 5.6 & 9.7 & 0.28 & \\
\hline \multirow[t]{7}{*}{ MPC } & BREC & 2 & BARC-044747-08795_BARC-054149-12354 & 126.2 & $124.0-128.4$ & 4.2 & 10.5 & 0.42 & 25.1 \\
\hline & & 5 & BARC-041257-07953_BARC-060051-16321 & 78.8 & $77.4-80.2$ & 3.4 & 8.4 & 0.38 & \\
\hline & & 15 & BARC-018901-03270_BARC-038977-07417 & 47.2 & $46.0-48.4$ & 3.2 & 9.2 & 0.41 & \\
\hline & DRC & 2 & BARC-028373-05856_Sat_198 & 116.5 & $116.0-117.0$ & 2.5 & 6.1 & 0.29 & 24.7 \\
\hline & & 5 & BARC-041257-07953_BARC-060051-16321 & 78.8 & $78.3-79.3$ & 2.5 & 5.7 & 0.29 & \\
\hline & & 6 & BARC-059997-16280_Sat_336 & 35.4 & $32.8-38.0$ & 4.6 & 12.3 & 0.41 & \\
\hline & & & Seed weight & & & & & & \\
\hline \multirow[t]{5}{*}{ MPB } & BREC & 6 & BARC-056271-14211_BARC-057469-14770 & 41.5 & $39.7-43.3$ & 3.8 & 6.4 & 0.49 & 24.5 \\
\hline & & 19 & Satt527_BARC-047496-12943 & 61.5 & $59.6-63.4$ & 3.9 & 7.0 & 0.54 & \\
\hline & & 1 & BARC-045297-08928_Satt184 & 16.7 & $14.7-18.7$ & 4.0 & 6.2 & -0.47 & \\
\hline & DRC & 6 & BARC-016957-02165_Satt281 & 26.1 & $21.4-30.8$ & 6.7 & 14.2 & 0.69 & 25.5 \\
\hline & & 19 & Satt527_BARC-047496-12943 & 61.5 & $56.1-66.9$ & 7.4 & 13.2 & 0.62 & \\
\hline \multirow[t]{5}{*}{ MPC } & BREC & 6 & BARC-059997-16280_Sat_336 & 35.4 & $34.9-35.9$ & 2.5 & 5.9 & 0.47 & 23.2 \\
\hline & & 19 & BARC-014885-01914_Satt527 & 61.5 & $58.8-64.2$ & 4.7 & 9.8 & 0.53 & \\
\hline & & 1 & BARC-038883-07384_Satt184 & 15.9 & $14.1-17.7$ & 3.8 & 7.9 & 0.48 & \\
\hline & $\mathrm{DRC}$ & 6 & BARC-059997-16280_Sat_336 & 35.4 & $34.9-35.9$ & 2.5 & 5.9 & 0.40 & 23.2 \\
\hline & & 19 & BARC-014885-01914_Satt527 & 61.5 & $60.3-62.7$ & 3.2 & 7.3 & 0.41 & \\
\hline
\end{tabular}

${ }^{\dagger}$ MPB, Magellan $\times$ PI 438489B; MPC, Magellan × PI 567516C.

${ }^{\ddagger}$ Chr., chromosome.

\$The QTL position was determined based on genetic linkage map constructed in the present study.

"Confidence interval for QTL location was estimated using a 1 - LOD support interval value as described by van Ooijen (1992).

\#LOD, logarithm of the odds.

${ }^{T+}$ Positive sign indicates alleles from Magellan and negative sign indicates alleles from PI 438489B or PI 567516C.

‡¥PVE, phenotypic variation explained.

one more QTL on Chr. 6 (between BARC-016957-02165 and Satt281) was identified in a single population and single environment. Another seed weight QTL mapped on Chr. 1 (between BARC-045297-08928 and Satt184) was identified in both populations but only in one environment, BREC. Remarkably, one QTL for protein and oil contents was also mapped in the same genomic region as QTL associated with seed weight on Chr. 6, an important location embracing QTL for three seed traits. Cultivar Magellan contributed favorable alleles (except on Chr. 1) and had large additive effects that increased seed weight.

\section{DISCUSSION}

In the MPB and MPC populations of this study, mean protein contents were 413 and $412 \mathrm{~g} \mathrm{~kg}^{-1}$ and mean oil contents were 180 and $181 \mathrm{~g} \mathrm{~kg}^{-1}$, respectively, and our results were in good agreement with previous studies (Fasoula et al., 2004; Hyten et al., 2004; Panthee et al., 
2005) and within the range of values of the Soybean Germplasm Collection (Wilson, 2004). Heritability for protein and oil contents and seed weight in our study was moderately high and similar to those reported by Hyten et al. (2004) and Panthee et al. (2005). The heritability observed in our populations indicated that much of the variation was genetic; therefore, selection response would be reasonable for achieving genetic gain.

We observed significant negative phenotypic and genotypic correlation between seed protein and oil contents in both mapping populations as reported in other studies (Chung et al., 2003; Hyten et al., 2004; Mansur et al., 1996; Panthee et al., 2005). These genotypic correlations indicate that it is difficult to simultaneously increase protein and oil contents and seed yield. Large variations in correlation (positive and negative as well as significant and nonsignificant) for seed weight with protein and oil have been reported (Reinprecht et al., 2006; Specht et al., 2001).

Due to a strong negative correlation between soybean seed protein and oil contents observed in this study and consistent with previous reports, we predicted that QTL and/or gene or genes associated with protein and oil contents may have pleiotropic effects. In our study, both traits were associated with the same genetic markers at some of the detected QTL across environments and genetic backgrounds. Quantitative trait loci with pleiotropic effects for protein and oil have been reported in several earlier studies (Brummer et al., 1997; Chung et al., 2003; Diers et al., 1992; Hyten et al., 2004; Mansur et al., 1996; Orf et al., 1999; Sebolt et al., 2000). However, the reverse was also true; a number of protein and oil QTL were identified independently in diverse genetic backgrounds and mapped in different genomic regions (Brummer et al., 1997; Mansur et al., 1993; Specht et al., 2001). So far no validated QTL was discovered with pleiotropic effects that simultaneously increased both seed protein and oil contents. We have compared QTL detected and mapped in our study with QTL previously reported within a $10-\mathrm{cM}$ vicinity. The soybean consensus genetic map (Hyten et al., 2010) was used for comparison and discussion because the consensus map contains all SNP markers of the USLP 1.0 array (Hyten et al., 2010) used in the present study. Also, we used the soybean composite genetic map (Song et al., 2004) for crosscomparison because it contains more restriction fragment length polymorphism (RFLP) and SSR markers and a few SNP markers. Three SNP markers (BARC-059985-16274, BARC-044639-08743, and BARC-059997-16280) located on Chr. 6 were consistently associated with protein and oil QTL in both populations and environments (Table 4). The SNP marker BARC-059997-16280 was also associated with seed weight QTL detected in both environments. One SSR marker, Sat_336, was associated with both oil and seed weight QTL and another SSR marker, Satt281, was also associated with protein and seed weight QTL. In this case, protein, oil, and seed weight QTL mapped to a common genomic region on Chr. 6. In same genomic region, Shi et al. (2010) earlier mapped protein and oil QTL and Orf et al. (1999) mapped oil QTL (Oil 9-2). So far, no seed weight QTL has been reported in this region. With the consistency and confirmation obtained in our study, it was concluded that this was a novel QTL impacting the seed weight trait. One protein QTL (between markers BARC041257-07953 and BARC-060051-16321) located on Chr. 5 was associated with seed oil QTL in both populations and environments. Previously, protein (Pro 2-1, Pro 9-1, and Pro 12-1), oil (Oil 3-2, Oil 10-1, and Oil 13-1), and seed weight (Sd wt 1-3 and Sd wt 10-1) QTL were mapped in the same genomic regions (Mansur et al., 1996; Orf et al., 1999; Specht et al., 2001). We were able to detect and consistently map protein and oil QTL on Chrs. 5 and 6 while using different genetic populations grown in different environments. Our results confirm similar findings of earlier genetic mapping studies.

One SSR maker (Satt632) located on Chr. 8 was consistently associated with protein QTL in MPC at both locations. Although a large number of protein and oil QTL have been mapped in the soybean genome, only a few were mapped on Chr. 8. Earlier, one oil (Oil 1-1) QTL (Mansur et al., 1993), protein (Pro 26-1) QTL (Reinprecht et al., 2006), and seed weight QTL (Sd wt 4-5, Sd wt 6-2, and Sd wt 13-1) (Hoeck et al., 2003; Maughan et al., 1996; Orf et al., 1999) were mapped close to Satt632 detected in our study. Two SNP markers (BARC-014705-01623 and BARC029825-06442) located on Chr. 7 were associated with seed protein in the MPB population in both environments. Three protein (Pro 12-4, Pro 13-4, and Pro 24-4) QTL (Csanadi et al., 2001; Hyten et al., 2004; Specht et al., 2001) and one oil (Oil 23-6) QTL (Hyten et al., 2004) were mapped about $12 \mathrm{cM}$ downstream of SNP marker BARC014705-01623. On Chr. 3, one protein QTL (between BARC-016199-02307 and BARC-053313-11792 in MPB and between BARC-028645-05979 and BARC-05514913089 in MPC) detected at BREC and oil QTL (between BARC-055637-13558 and BARC-057823-14942) were detected in one location and in one population. Lee et al. (1996) reported two protein QTL (Pro 4-8 and Pro 4-9) and Qi et al. (2011) detected two oil QTL (Oil 24-5 and Oil 24-13) in this region. On Chr. 2, an oil QTL (between markers BARC-044747-08795 and BARC054149-12354) was identified in the MPC population in both environments. Two oil QTL earlier reported (Oil 19-1 and Oil 24-3) were mapped close to above SNP markers (Panthee et al., 2005; Qi et al., 2011). On Chr. 15, an oil QTL (between BARC-039687-07541 and BARC042349-08247) was detected in the MPB population at both locations and another protein QTL (between BARC018923-03037 and BARC-025493-06513) was identified at DRC in the MPB population and mapped close to the 
oil QTL. Earlier, protein and oil contents and seed weight QTL were mapped in the same genomic region (Diers et al., 1992; Lee et al., 1996; Qi et al., 2011).

An important QTL for seed weight was mapped on Chr. 19 (between marker Satt527 and BARC-04749612943 and marker BARC-014885-01914 and Satt527), which was detected in both genetic backgrounds and environments and explained total phenotypic variation of about 10\% (Table 4). This result was in agreement with previously reported seed weight QTL (Sd wt 5-1 and Sd wt 15-7) (Hyten et al., 2004; Orf et al., 1999). In our study, another seed weight QTL (BARC-045297-08928_Satt184) was consistently mapped on Chr. 1 in the MPB population across environments. The result was in good agreement with the findings as reported by Panthee et al. (2005).

We were able to successfully detect several major QTL for seed protein and oil contents and seed weight in one mapping population and were able to confirm the consistency of genetic position with confidence interval estimation (van Ooijen, 1992) in another genetic background in two different environments. Although we did not find new QTL for protein or oil contents, however, in the present study we were able to reconfirm previous findings. Reconfirmed protein and oil QTL on Chrs. 5 and 6 flanked by SSR and SNP markers may be important targets, leading to the identification of candidate genes involved in modification of protein and oil using genetic and genomic approaches. We did find a new QTL for seed weight on Chr. 6 at the same genomic region of protein and oil QTL. Reconfirmed seed weight QTL on Chr. 19 along with the new QTL warrant further investigation. Simple sequence repeat and SNP markers tightly associated with QTL regions without pleiotrophic effects may be used in marker-assisted breeding programs to develop new soybean germplasm and cultivars with high protein and oil contents. Moreover, these genetic markers would facilitate development of near-isogenic lines using marker-assisted backcrossing, which could lead to fine mapping and map-based gene cloning for high protein and oil contents and higher seed weight in soybean.

\section{Acknowledgments}

Authors wish to thank the United Soybean Board for financial support through the Better Bean Initiative. We also wish to thank the Missouri Agricultural Experiment Station for supporting field evaluations, Christine Cole, Culian Liu, and Md Sariful Islam for their technical assistance in phenotyping and genotyping the populations.

\section{References}

AOAC Int. 2005. Official methods of analysis of AOAC International. 18th ed. AOAC International, Gaithersburg, MD.

Barnes, R.J., M.S. Dhanoa, and S.J. Lister. 1989. Standard normal variate transformation and de-trending of near-infrared diffuse reflectance spectra. Appl. Spectrosc. 43:772-777. doi:10.1366/0003702894202201
Birt, D.F., S. Hendrick, and D.L. Alekel. 2004. Soybean and the prevention of chronic human disease. In: H.R. Boerma and J.E. Specht, editors, Soybean: Improvement, production, and uses. Agron. Monogr. No. 16. ASA-CSSA-SSSA, Madison, WI. p. 1047-1117.

Brim, C.A. 1966. A modified pedigree method of selection in soybeans. Crop Sci. 6:220. doi:10.2135/cropsci1966.0011183 X000600020041x

Brim, C.A. 1973. Quantitative genetics and breeding. In: B.E. Caldwell, editor, Soybean: Improvement, production, and uses. ASA, Madison, WI. p. 155-186.

Brumm, T.J., and C.R. Hurburgh. 1990. Estimating the processed value of soybean. J. Am. Oil Chem. Soc. 67:302-307. doi:10.1007/BF02539680

Brumm, T.J., and C.R. Hurburgh. 2006. Changes in long-term soybean compositional patterns. J. Am. Oil Chem. Soc. 83(11):981-982. doi:10.1007/s11746-006-5056-4

Brummer, E.C., G.L. Graef, J.H. Orf, J.R. Wilcox, and R.C. Shoemaker. 1997. Mapping QTL for seed protein and oil content in eight soybean populations. Crop Sci. 37:370-378. doi:10.2135/cropsci1997.0011183X003700020011x

Burton, J.W. 1987. Quantitative genetics: Results relevant to soybean breeding. In: J.R. Wilcox, editor, Soybean: Improvement, production, and uses. 2nd ed. ASA, Madison, WI. p. 211-247.

Clarke, F.J., and J. Wiseman. 2000. Developments in plant breeding for improved nutritional quality in soybean. I. Protein and amino acids content. J. Agric. Sci. 134:111-124. doi:10.1017/ S0021859699007431

Chung, J., H.L. Babka, G.L. Graef, P.E. Staswick, D.J. Lee, P.B. Cregan, R.C. Shoemaker, and J.E. Specht. 2003. The seed protein, oil, and yield QTL on soybean linkage group I. Crop Sci. 43:1053-1067. doi:10.2135/cropsci2003.1053

Churchill, G.A., and R.W. Doerge. 1994. Empirical threshold values for quantitative trait mapping. Genetics 138:963-971.

Csanadi, G., J. Vollmann, G. Stift, and T. Lelley. 2001. Seed quality QTL identified in a molecular map of early maturing soybean. Theor. Appl. Genet. 103:912-919. doi:10.1007/ s001220100621

Diers, B.W., P. Keim, W.R. Fehr, and R.C. Shoemaker. 1992. RFLP analysis of soybean seed protein and oil content. Theor. Appl. Genet. 83:608-612. doi:10.1007/BF00226905

Duckworth, J.H. 1998. Spectroscopic quantitative analysis. In: J. Workman Jr. and A. Springsteen, editors, Applied spectroscopy. A compact reference for practitioners. Academic Press, San Diego, CA. p. 93-190.

Falconer, D.S., and T.F.C. Mackay. 1996. Introduction to quantitative genetics. 4th ed. Longman Group Ltd., Boston, MA.

Fasoula, V.A., D.K. Harris, and H.R. Boerma. 2004. Validation and designation of quantitative trait loci for seed protein, seed oil, and seed weight from two soybean populations. Crop Sci. 44:1218-1225. doi:10.2135/cropsci2004.1218

Friedman, M., and D.L. Brandon. 2001. Nutritional and health benefits of soy proteins. J. Agric. Food Chem. 49:1069-1086. doi:10.1021/jf0009246

Hoeck, J.A., W.R. Fehr, R.C. Shoemaker, G.A. Welke, S.L. Johnson, and S.R. Cianzio. 2003. Molecular marker analysis of seed size in soybean. Crop Sci. 44:68-74. doi:10.2135/ cropsci2003.0068

Hurburgh, C.R., Jr. 1994. Component pricing of soybean at the country elevator. In: Component pricing of soybean. Report \# AE-470. Dep. of Ag. Econ., University of Illinois, Urbana, IL. 
Hyten, D.L., I.-Y. Choi, Q. Song, J.E. Specht, T.E. Carter, R.C. Shoemaker, E.-Y. Hwang, L.K. Matukumalli, and P.B. Cregan. 2010. A high density integrated genetic linkage map of soybean and the development of a 1536 universal soy linkage panel for QTL mapping. Crop Sci. 50:960-968. doi:10.2135/cropsci2009.06.0360

Hyten, D.L., V.R. Pantalone, C.E. Sams, A.M. Saxton, D. Landau-Ellis, T.R. Stefaniak, and M.E. Schmidt. 2004. Seed quality QTL in a prominent soybean population. Theor. Appl. Genet. 109:552-561. doi:10.1007/s00122-004-1661-5

InfraSoft. 1999. Windows near infrared software, version 1.02. InfraSoft International, Port Matilda, PA.

Lee, S.H., M.A. Bailey, M.A.R. Mian, T.E. Carter Jr., E.R. Shipe, D.A. Ashley, W.A. Parrott, R.S. Hussey, and H.R. Boerma. 1996. RFLP loci associated with soybean seed protein and oil content across populations and locations. Theor. Appl. Genet. 93:649-657. doi:10.1007/BF00224058

Mahmoud, A.A., S.S. Natarajan, J.O. Bennett, T.P. Mawhinney, W.J. Wiebold, and H.B. Krishnan. 2006. Effect of six decades of selective breeding on soybean protein composition and quality: A biochemical and molecular analysis. J. Agric. Food Chem. 54:3916-3922. doi:10.1021/jf060391m

Mansur, L.M., K.G. Lark, H. Kross, and A. Oliveira. 1993. Internal mapping of quantitative trait loci for reproductive, morphological, and seed traits of soybean (Glycine max L.). Theor. Appl. Genet. 86:907-913.

Mansur, L.M., J.H. Orf, K. Chase, T. Jarvik, P.B. Cregan, and K.G. Lark. 1996. Genetic mapping of agronomic traits using recombinant inbred lines of soybean. Crop Sci. 36:1327-1336. doi:10.2135/cropsci1996.0011183X003600050042x

Maughan, P.J., M.A.S. Maroof, and G.R. Buss. 1996. Molecularmarker analysis of seed-weight: Genomic locations, gene action, and evidence for orthologous evaluation among three legume species. Theor. Appl. Genet. 93:574-579. doi:10.1007/ BF00417950

Nichols, D.M., K.D. Glover, S.R. Carlson, J.E. Specht, and B.W. Diers. 2006. Fine mapping of a seed protein QTL on soybean linkage map I and its correlated effects on agronomic traits. Crop Sci. 46:834-839. doi:10.2135/cropsci2005.05-0168

Nyquist, W.E. 1991. Estimation of heritability and prediction of selection responses in plant populations. Crit. Rev. Plant Sci. 10:235-322. doi:10.1080/07352689109382313

Orf, J.H., K. Chase, T. Jarvik, L.M. Mansur, P.B. Cregan, F.R. Adler, and K.G. Lark. 1999. Genetics of soybean agronomic traits: I. Comparison of three related recombinant inbred populations. Crop Sci. 39:1642-1651. doi:10.2135/ cropsci1999.3961642x

Orf, J.H., and T.C. Helms. 1994. Selection to maximize gross value per hectare within three soybean populations. Crop Sci. 34:11631167. doi:10.2135/cropsci1994.0011183X003400050004x

Panthee, D.R., V.R. Pantalone, D.R. West, A.M. Saxton, and C.E. Sams. 2005. Quantitative trait loci for seed protein and oil contents, and seed size in soybean. Crop Sci. 45:20152022. doi:10.2135/cropsci2004.0720

Qi, Z.-M., Q. Wu, X. Han, Y.-N. Sun, X.-Y. Du, C.-Y. Liu, H.-W. Jiang, G.-H. Hu, and Q.-S. Chen. 2011. Soybean oil content QTL mapping and integrating with meta-analysis method for mining genes. Euphytica 179:499-514. doi:10.1007/s10681011-0386-1

Reinprecht, Y., V.W. Poysa, K.F. Yu, I. Rajcan, G.R. Ablett, and K.P. Pauls. 2006. Seed and agronomic QTL in low linolenic acid, lipoxygenase-free soybean [Glycine max (L.) Merrill] germplasm. Genome 49:1510-1527. doi:10.1139/g06-112

Rotundo, J.L., L. Borras, M.E. Westgate, and J.H. Orf. 2009. Relationship between assimilates supply per seed during seed filling and soybean seed composition. Crop Sci. Res. 112:9096. doi:10.1016/j.fcr.2009.02.004

SAS Institute. 2002. SAS proprietary software version 9.2. SAS Inst., Cary, NC.

Schapaugh, W.T., P.A. Owen, K.M. Clark, and D.A. Sleper. 1998. Registration of 'Magellan' soybean. Crop Sci. 38:892.

Sebolt, A.M., R.C. Shoemaker, and B.W. Diers. 2000. Analysis of a quantitative trait locus allele from wild soybean that increases seed protein concentration in soybean. Crop Sci. 40:1438-1444. doi:10.2135/cropsci2000.4051438x

Shenk, J.S., and M.O. Westerhaus. 1991. Population structuring of near infrared spectra and modified partial least squares regression. Crop Sci. 31:1548-1555. doi:10.2135/cropsci1991. 0011183X003100060034x

Shi, A., P. Chen, B. Zhang, and A. Hou. 2010. Genetic diversity and association analysis of protein and oil content in foodgrade soybeans from Asia and the United States. Plant Breed. 129:250-256. doi:10.1111/j.1439-0523.2010.01766.x

Song, Q.J., L.F. Marek, R.C. Shoemaker, K.G. Lark, V.C. Concibido, X. Delannay, J.E. Specht, and P.B. Cregan. 2004. A new integrated genetic linkage map of the soybean. Theor. Appl. Genet. 109:122-128. doi:10.1007/s00122-004-1602-3

SOYSTATS. 2011. A reference guide to important soybean facts and figures. American Soybean Association, St. Louis, Missouri. http://soystats.com/2011/Default-frames.htm (accessed 28 Feb. 2012).

Specht, J.E., M. Germann, J.P. Markwell, K.G. Lark, J.H. Orf, M. Macrander, K. Chase, J. Chung, and J.L. Graef. 2001. Soybean response to water: A QTL analysis of drought tolerance. Crop Sci. 41:493-509. doi:10.2135/cropsci2001.412493x

Thorne, J.C., and W.R. Fehr. 1970. Incorporation of high protein, exotic germplasm into soybean populations by 2- and 3-way crosses. Crop Sci. 10:652-655. doi:10.2135/cropsci1970.0011 183X001000060012x

USDA. 2005. Historical track records. April 2005. U.S. Department of Agriculture, National Agricultural Statistics Service, Washington, DC. http://usda01.library.cornell. edu/usda/nass/htrcp//2000s/2005/htrcp-04-01-2005.pdf (accessed 1 Jan. 2011).

USDA Agricultural Research Service Germplasm Resources Information Network (USDA-ARS-GRIN). 2012. Search GRIN, accession area queries, text search query. USDAARS Germplasm Resources Information Network (GRIN), Washington, DC. http://www.ars-grin.gov/npgs/acc/acc_ queries.html (accessed 12 Feb. 2012).

van Ooijen, J.H., and R.E. Voorrips. 2001. JoinMap 3.0 software for the calculation of genetic linkage maps. Plant Research International, Wageningen, The Netherlands.

van Ooijen, J.W. 1992. Accuracy of mapping quantitative trait loci in autogamous species. Theor. Appl. Genet. 84:803-811.

van Ooijen, J.W. 2004. MapQTL 5, software for the mapping of quantitative trait loci in experimental populations. Kyazma B.V., Wageningen, The Netherlands.

Voorrips, R.E. 2002. MapChart: Software for the graphical presentation of linkage maps and QTL. J. Hered. 93:77-78. doi:10.1093/jhered/93.1.77

Vuong, T.D., D.A. Sleper, J.G. Shannon, X. Wu, and H.T. Nguyen. 2010. Novel quantitative trait loci for broad-based resistance to soybean cyst nematode (Heterodera glycines I.) in soybean PI 
567516C. Theor. Appl. Genet. 121:1253-1266. doi:10.1007/ s00122-010-1385-7

Vuong, T.D., D.A. Sleper, J.G. Shannon, X. Wu, and H.T. Nguyen. 2011. Confirmation of quantitative trait loci for resistance to multiple-HG types of soybean cyst nematode (Heterodera glycines I.). Euphytica 181:101-113. doi:10.1007/s10681-0110430-1

Wilcox, J.R. 1998. Increasing seed protein in soybean with eight cycles of recurrent selection. Crop Sci. 38:1536-1540. doi:10.2135/cropsci1998.0011183X003800060021x
Wilcox, J.R., and Z. Goudong. 1997. Relationships between seed yield and seed protein in determinate and indeterminate soybean populations. Crop Sci. 37:361-364. doi:10.2135/cro psci1997.0011183X003700020009x

Wilson, R.F. 2004. Seed composition. In: H.R. Boerma and J.E. Specht, editors, Soybean: Improvement, production, and uses. Agron. Monogr. No. 16. ASA-CSSA-SSSA, Madison, WI. p. 621-677.

Yue, P., D.A. Sleper, and P.R. Arelli. 2000. Genetic analysis of resistance to soybean cyst nematode in PI438489B. Euphytica 116:181-186. doi:10.1023/A:1004054731652 